\title{
Recent advances in understanding the regulation of
}

\section{metalloproteinases [version 1; peer review: 2 approved]}

\author{
David A. Young (D), Matt J. Barter, David J. Wilkinson
}

Skeletal Research Group, Institute of Genetic Medicine, Central Parkway, Newcastle University, Newcastle upon Tyne, NE1 3BZ, UK

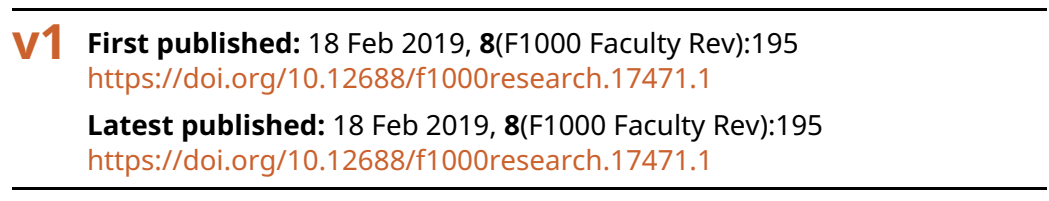

\section{Abstract}

Metalloproteinases remain important players in arthritic disease, in part because members of this large enzymatic family, namely matrix metalloproteinase-1 (MMP-1) and MMP-13, are responsible for the irreversible degradation of articular cartilage collagen. Although direct inhibition of MMPs fell out of vogue with the initial clinical disappointment of the first generation of compounds, interest in other mechanisms that control these important enzymes has always been maintained. Since these enzymes are critically important for tissue homeostasis, their expression and activity are tightly regulated at many levels, not just by direct inhibition by their endogenous inhibitors the tissue inhibitors of metalloproteinases (TIMPs). Focussing on MMP-13, we discuss recent work that highlights new discoveries in the transcriptional regulation of this enzyme, from defined promoter functional analysis to how more global technologies can provide insight into the enzyme's regulation, especially by epigenetic mechanisms, including non-coding RNAs. In terms of protein regulation, we highlight recent findings into enzymatic cascades involved in MMP-13 regulation and activation. Importantly, we highlight a series of recent studies that describe how MMP-13 activity, and in fact that of other metalloproteinases, is in part controlled by receptor-mediated endocytosis. Together, these new discoveries provide a plethora of novel regulatory mechanisms, besides direct inhibition, which with renewed vigour could provide further therapeutic opportunities for regulating the activity of this class of important enzymes.

Keywords

metalloproteinase, transcription, cartilage, osteoarthritis, regulation

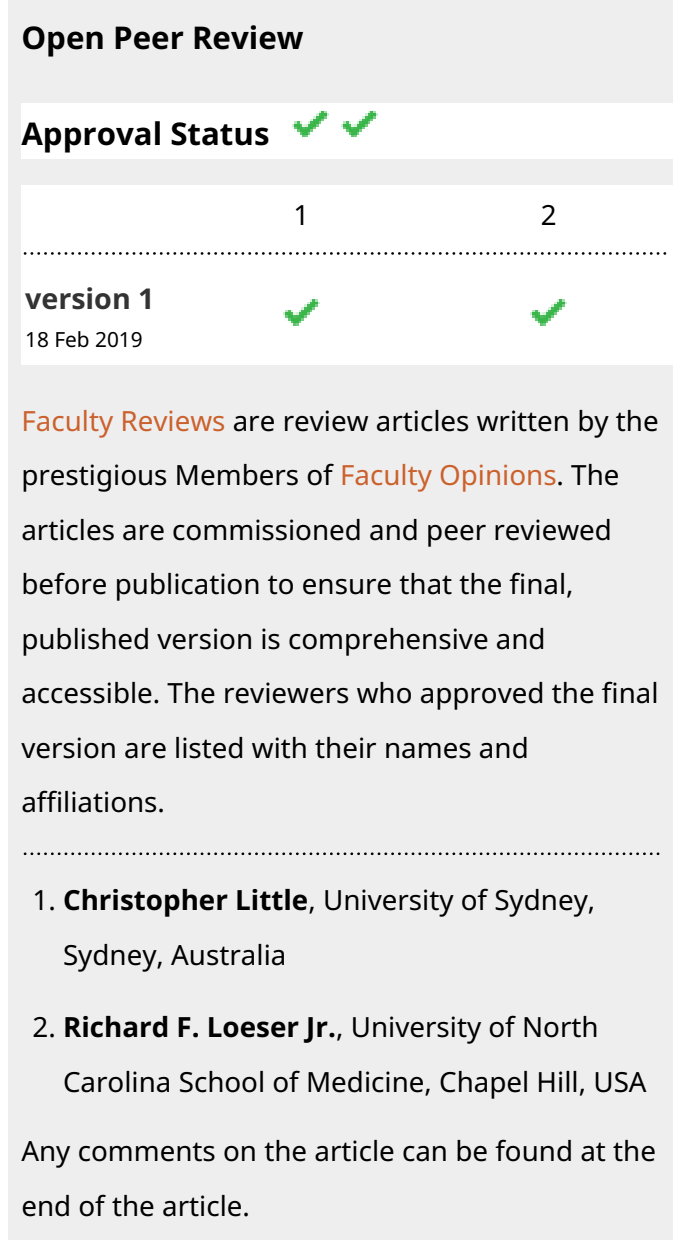


Corresponding author: David A. Young (david.young@ncl.ac.uk)

Author roles: Young DA: Conceptualization, Project Administration, Supervision, Writing - Original Draft Preparation, Writing - Review \& Editing; Barter MJ: Writing - Original Draft Preparation, Writing - Review \& Editing; Wilkinson DJ: Writing - Original Draft Preparation, Writing - Review \& Editing

Competing interests: No competing interests were disclosed.

Grant information: This work was supported by the Medical Research Council (MRC) and Arthritis Research UK as part of the MRCArthritis Research UK Centre for Integrated Research into Musculoskeletal Ageing (grants JXR 10641 and MR/P020941/1), Arthritis Research UK (grant 20199), the JGW Patterson Foundation, and the Dunhill Medical Trust.

The funders had no role in study design, data collection and analysis, decision to publish, or preparation of the manuscript.

Copyright: ( 2019 Young DA et al. This is an open access article distributed under the terms of the Creative Commons Attribution License, which permits unrestricted use, distribution, and reproduction in any medium, provided the original work is properly cited.

How to cite this article: Young DA, Barter MJ and Wilkinson DJ. Recent advances in understanding the regulation of metalloproteinases [version 1; peer review: 2 approved] F1000Research 2019, 8(F1000 Faculty Rev):195

https://doi.org/10.12688/f1000research.17471.1

First published: 18 Feb 2019, 8(F1000 Faculty Rev):195 https://doi.org/10.12688/f1000research.17471.1 


\section{Introduction}

Osteoarthritis (OA), affecting millions of people worldwide, is the most prevalent arthritic disease. The aetiology of the disease is complex and it has a number of risk factors but age predominates; in fact, in the UK, more than one in three adults over 45 years old have sought treatment for $\mathrm{OA}^{1}$. OA occurs in an insidious manner with distinct molecular pathways resulting in progressive cartilage loss, osteophyte formation, subchondral bone thickening and often a degree of synovial inflammation. There are currently no effective treatments which alter disease progression.

Although $\mathrm{OA}$ is a disease of the whole articulating joint, the proteolytic destruction of cartilage, especially of type II collagen, is a central and irreversible process that underpins OA. Cartilage is composed predominantly of type II collagen and the proteoglycan aggrecan. Collagen loss is particularly important because of its slow turnover, making this process essentially irreversible ${ }^{2}$. Collagens are defined by their unique triple-helical structure which limits their susceptibility to cleavage at a single site in the triple helix ( $\mathrm{PQG}_{775} \downarrow_{776} \mathrm{LAG}$ ) to a very specific group of proteinases ${ }^{3}$. With antibodies raised against the C-terminal neoepitopes generated by proteinase cleavage at this region, an increase in immuno-staining has been observed in aged cartilage and even more so in OA cartilage ${ }^{4-6}$. Along with this wealth of human data, recent strong evidence that this specific cleavage is essential in cartilage destruction comes from transgenic mice with mutated amino acids around the cleavage site in collagen (to $\mathrm{PPG}_{775} \downarrow_{775}$-MPG), which blocks proteolysis at the primary collagenase cleavage site. This mutation had no impact on normal collagen fibrillogenesis, but heterozygous collagen cleavage-resistant mice, when subjected to the surgically induced post-traumatic OA model, destabilisation of the medial meniscus (DMM), were highly protected ${ }^{7}$. In terms of the proteinases involved, it is well established that it is the matrix metalloproteinases (MMPs), especially the soluble collagenases MMP-1, MMP-8 and MMP-13, that are crucial for this destruction to occur, and prevailing dogma suggests that, in OA, MMP-13 predominates $^{3}$. Other MMPs such as MMP-2 and MMP-14 have reported collagenolytic activity but their contribution to cartilage pathology is likely minor. MMP-3, MMP-9 and MMP-10 degrade other extracellular matrix (ECM) components but, in vivo, are unable to cleave native type II collagen. Again, the importance of MMP-13 in type II collagen cleavage is supported by the DMM-OA model when performed in $\mathrm{Mmp} 3^{-/-}$mice. In this model, $\mathrm{Mmp} 13^{-/-}$mice show less tibial cartilage erosion than do wild-type mice at 8 weeks postsurgery $^{8}$. Conversely, cartilage-restricted expression of a constitutively active MMP-13 in mice induces a joint pathology that strongly resembles $\mathrm{OA}^{9}$.

Mice deficient in MMP-13 are grossly indistinguishable from wild-type animals and have normal fecundity, and a normal lifespan and no overt phenotypic abnormalities ${ }^{10,11}$. However, when challenged, the mice do show increased collagen deposition in the intima of aortic lesions ${ }^{12}$, whereas upon fullthickness cutaneous wounding, Mmp $13^{-/-}$mice have delayed re-epithelialisation ${ }^{13}$. Together, these studies show that MMP13 has a role in atherosclerosis and would healing, highlighting a role for the enzyme beyond cartilage. In terms of skeletal development, histological analysis of developing $M m p 13^{-/-}$ animals shows an expanded growth plate, which is due to enlargement of the hypertrophic zone. The animals thus show a profound delay in development of the primary ossification centre, which begins to normalise after birth ${ }^{10,11}$. Interestingly, in skeletally mature animals, both the tibial and femoral growth plates of $\mathrm{Mmpl3}^{-/}$mice have focal regions of bony union, something unseen in wild-type littermates ${ }^{8}$. Many of the growth plate features of the $M m p 13^{-/}$mice are consistent with the human chondrodysplasia group metaphyseal anadysplasia 1 (which includes Missouri-type spondyloepimetaphyseal dysplasia) and are caused by a mutation in MMP-13 and can improve spontaneously by early adolescence ${ }^{14-16}$.

Together, these observations highlight MMPs, and especially MMP-13, as critical players in cartilage collagen destruction. Moreover, MMP-13 can cleave a wealth of other matrix molecules, including type IV and IX collagen, perlecan, osteonectin and proteoglycans ${ }^{17}$. Given this, a large body of work and studies revolved around generating and testing chemical inhibitors of MMPs. However, selective targeting of MMPs, including the collagenases, represents a significant challenge as they exhibit a high degree of structural similarity across their active sites $^{3,18}$. Indeed, owing to poor selectivity, many MMP inhibitors displayed off-target effects in clinical trials and had noticeable side effects, including joint arthralgia ${ }^{19}$. Thus, for a long period, MMP-13 inhibition has been out of vogue. However, recent developments are beginning to allow the prospect of selectively removing MMP-13 activity from OA cartilage, be it biologically, biochemically or genetically. In the following sections, we discuss recent publications characterising mechanisms of MMP regulation at these various levels and focus on MMP-13.

\section{Regulation by MMP13 transcription}

Evolution of $M M P$ family members occurred via gene duplication predisposing commonalities in promoter sequence and regulation $^{20}$. Many MMPs, especially those duplicated in the human chromosomal region $11 \mathrm{q} 22$, have well-defined promoter elements with a conserved TATA sequence at about -30 base pairs (bp) and an AP-1 binding site at about $-70 \mathrm{bp}^{21,22} . M M P 1$ and $M M P 13$ also possess an ETS-domain transcription factor PEA3-binding site adjacent to the proximal AP-1 site ${ }^{21,22}$. Additional AP-1 sites are present in many MMP promoters.

For many years, it has been shown that numerous stimuli induce the expression of $M M P s$ in cartilage, including pro-inflammatory cytokines such as interleukin-1 (IL-1), IL-6, IL-17, and tumour necrosis factor alpha $(\mathrm{TNF} \alpha)$ as well as pleiotropic cytokines such as oncostatin M (OSM) and growth factors ${ }^{23-27}$. Many of these cytokines and growth factors trigger intracellular signalling pathways, such as the extracellular signal-regulated kinase (ERK), Jun N-terminal kinase (JNK) and p38 mitogenactivated protein kinase (MAPK) pathways, causing expression and activation of AP-1 factors c-Jun and c-Fos and ETS transcription factor family members to directly induce $M M P$ transcription $^{28,29}$. Nuclear factor-kappa B (NF- $\left.\mathrm{BB}\right)$ pathway activation of $\mathrm{I} \kappa \mathrm{B}$ releases $\mathrm{p} 50(\mathrm{NF}-\kappa \mathrm{B} 1) / \mathrm{p} 65(\mathrm{RelA})$ to activate $M M P$ gene expression ${ }^{28}$. However, even given this long-standing 
knowledge, the mechanism by which these cytokines and transcription factors directly impact on MMP expression has proven to be somewhat elusive.

Recently, the binding of c-Fos to the MMP13 proximal promoter in articular chondrocytes was confirmed via chromatin immunoprecipitation (ChIP), but only transiently at an early time point (1 hour), inconsistent with the later MMP13 induction (6-24 hours $)^{30}$. Instead, c-Fos was proposed to mediate induction of ATF3, which itself goes on to bind to the MMP13 proximal AP-1 site to regulate the gene $^{30}$. In a subsequent study, Baker et al. describe how IL-1, combined with OSM, acts via protein kinase D3 (PKD3), downstream of protein kinase C (PKC) signalling, to regulate ATF3 expression and therefore $M M P 1$ and $M M P 13$ expression in chondrocytes ${ }^{31}$.

Toll-like receptor (TLR) agonists such as RNA/DNA and matrix components or fibronectin fragments also induce MMP expression through activation of MAPK and NF- $\kappa B$ pathways ${ }^{32-34}$. Previously, protein kinase R (PKR), which is activated by dsRNA, had been implicated in cytokine-mediated gene expression in chondrocytes ${ }^{35}$. Ma et al. now show that TNF $\alpha$-induced phosphorylation of PKC is dependent on PKR which subsequently activates NADPH oxidase generation of reactive oxygen species and the ERK and NF- $\mathrm{KB}$ signalling pathways ${ }^{36}$. This ERK pathway activation also prevented the peroxisome proliferator-activated receptor gamma (PPAR $\gamma$ )-mediated inhibition of $M M P 13$, which has previously been described ${ }^{37}$. It remains unclear how TNF $\alpha$ activates PKR in chondrocytes, but interactions between TNF receptor-associated factor (TRAF) and PKR are $\mathrm{known}^{38}$. Separately, Ma et al. showed that advanced glycation products cause suppression of PPAR $\gamma$ levels to upregulate $M M P 13$ expression ${ }^{36}$.

The IL-1 induction of MMP13 expression is also partially dependent on zinc transporter Zip8-mediated zinc influx ${ }^{39}$. Increased zinc induces $M M P 13$ expression, and expression of other MMPs, mediated to some extent by Mtf1 although other transcription factors are also activated ${ }^{39}$. Mtf1 overexpression is able to induce $M M P 13$ expression, but no direct interaction with the $M M P 13$ promoter was explored ${ }^{39}$. Stress-inducible nuclear protein 1 (Nupr1) was also recently implicated in the IL-1 induction of MMP-13 expression ${ }^{40}$. Elsewhere, Nupr1 was identified in combination with c-Jun at the MMP13 promoter $^{41}$.

During endochondral ossification, MMP-13 expression is tightly restricted to chondrocytes of the lower zone of hypertrophic cartilage which also express type $\mathrm{X}$ collagen ${ }^{42}$. Examining what processes contribute to the hypertrophy of chondrocytes characteristic of OA, Bianchi et al. demonstrate that FGF23, which is upregulated in human OA cartilage, induces expression of MMP13 in chondrocytes via FGF receptor $1^{43}$. $\alpha$-Klotho acts as a co-receptor for FGF23 but was not required in this context; however, Chuchana et al. determined that treatment of human chondrocytes with recombinant $\alpha$-Klotho or $\alpha$-Klotho-targeting small interfering RNA (siRNA) suppressed or induced $M M P 13$ expression, respectively ${ }^{44}$. The mechanism was not examined, but elsewhere $\alpha$-Klotho is reported to disrupt signalling pathways, including Wnt, transforming growth factor-beta (TGF- $\beta$ ) and insulin-like growth factor (IGF) ${ }^{44,45}$. The authors suggest a chondroprotective role for $\alpha$-Klotho in OA, although more detailed in vivo experiments are needed ${ }^{44}$. Notch signalling plays a key role in skeletal development where it can regulate chondrocyte differentiation ${ }^{46}$. Notch may also play a role in OA development, and Sugita et al. showed that Hes1, a transcription factor and important target of Notch signalling, can directly induce $M M P 13$ expression via binding to a regulatory element within intron 4 of the gene ${ }^{47}$.

Genomic enhancer regions can function across large distances and are emerging as key elements for transcriptional regulation in skeletal biology and development ${ }^{48}$. Gene expression is directed by the interplay of different enhancers and tissuespecific promoter elements, such as the osteoblast-specific element upstream of $M M P 13$ transcription start site ${ }^{21}$. Previously, AP-1 ChIP-sequencing (ChIP-seq) identified a $-20 \mathrm{\kappa B}$ IL-1-responsive enhancer regulating MMP13 expression in chondrocytes $^{49}$. More recently, Meyer et al. used ChIP-seq to identify $-10 \mathrm{\kappa B}$ and $-30 \mathrm{\kappa B}$ upstream transcription factor binding enhancer sites required for vitamin $\mathrm{D}$ receptor and basal MMP13 expression, respectively, in osteoblasts ${ }^{50,51}$. Large consortia projects such as ENCODE and Roadmap have characterised the genomic landscape to identify the whereabouts of histone modifications and transcription factors in numerous cell types ${ }^{52}$. Until recently, the chondrocyte landscape remained unexplored, but Liu et al. now present ATAC-seq (assay for transposase-accessible chromatin using sequencing) mapping of accessible chromatin regions in chondrocytes ${ }^{53}$. From the reported data, transcription factor binding sites inferred by accessibility for $M M P 1$ and $M M P 13$ include C/EBP:AP-1, STAT3/4, NF1 and Fra $1^{53}$. These intriguing findings now require experimental validation.

Countering the induction of $M M P s$, anabolic growth factors such as TGF- $\beta$, IGF1, interferon gamma (IFN $\gamma$ ) and retinoic acid can repress the expression of $M M P 13$, often by repression of intermediate transcription factor induction or activation or by direct competition for binding sites with AP-1 $28,54,55$. Santoro et al. recently showed that treatment of cells with recombinant serine proteinase inhibitor SERPINE2 (protease nexin-1) also inhibits IL-1-induced expression of MMP-13 as well as ERK and NF- $\mathrm{KB}$ pathway activation and c-Jun levels, although the mechanism of the SERPINE2 effect was not explored ${ }^{56}$.

Mechanical loading of cartilage in the form of compression, tension and shear also regulates $M M P$ expression ${ }^{57}$. Overloading causes upregulation of MMPs and cartilage degradation, whereas moderate physiological levels of loading on cartilage are considered critical for maintaining cartilage integrity ${ }^{58}$. In fact, moderate compression appears to repress $M M P 1$ and $M M P 13$ expression by upregulating mechanosensitive transcriptional co-regulatory CITED2 $2^{59}$, the activation of which occurs via the primary cilia and subsequent ERK MAPK pathway activation $^{60}$. However, the beneficial effect of physiological loading on cartilage may be mediated more by upregulating anabolic activity, as an assessment of the literature by Bleuel et al. implies that there is little downregulation of proteases under any loading conditions $\mathbf{s}^{57}$. 
The role of epigenetic mechanisms, including histone modifications and DNA methylation, in $M M P$ expression is well documented ${ }^{61}$. Histone deacetylase (HDAC) inhibitors regulate both basal and cytokine-induced $M M P$ expression, in general repressing the cytokine-induced expression of $M M P 1$ and $M M P 13^{62,63}$. Previously, the class III HDAC SIRT1 has been demonstrated to promote cartilage anabolism and enhance chondrocyte survival in vitro and in vivo. Elayyan et al. extended their previous studies by examining the role of SIRT1 in catabolic chondrocyte gene expression ${ }^{64}$. IL-1 activated Wnt signalling and induced LEF1 levels to upregulate $M M P 13$, processes that are counteracted by SIRT1 which directly represses LEF1 expression, although the mechanism remains elusive ${ }^{64}$. GDF5 plays a key role in joint development, and the GDF5 locus harbours polymorphisms associated with $\mathrm{OA}$ but its function in cartilage homeostasis is less well known ${ }^{65,66}$. Enochson et al. demonstrated that GDF5 also represses MMP13 expression in human articular chondrocyte pellets by inhibiting canonical Wnt signalling via DKK1 upregulation ${ }^{67}$. However, Ratnayake et al. were unable to identify a consistent MMP1 or MMP13 response to GDF5 treatment in monolayer or micromass chondrocytes $^{68}$.

DNA methylation at MMP13 proximal promoter CpGs has previously been shown to interfere with the binding of transcription factors CREB and HIF2 $\alpha$, thereby regulating gene expression ${ }^{69,70}$. RUNX2 is also able to trans-activate the MMP13 promoter, and Takahashi et al. reported that the upregulation of RUNX2 in OA correlated with reduced promoter methylation, and they further confirmed a loss of methylation at numerous MMP13 proximal promoter $\mathrm{CpGs}$ - in line with the upregulation of $M M P 13$ during $\mathrm{OA}^{71}$. DNA methylation arrays assessing changes in OA compared with undamaged or healthy control tissue have identified differentially methylated CpGs at both MMP13 and MMP1 loci ${ }^{72,73}$, although the functional consequences of these require testing.

MicroRNAs (miRNAs) post-transcriptionally regulate gene expression, and numerous miRNAs have postulated roles in skeletal biology and regulation of chondrocyte function ${ }^{74}$. MMP13 has a relatively short $3^{\prime}$ untranslated region (3'-UTR) with few predicted miRNA binding sites ${ }^{75}$. However, a number of miRNA interactions have been experimentally validated in vitro, including for miRNAs $27 \mathrm{~b}-3 \mathrm{p}, 125 \mathrm{~b}-5 \mathrm{p}$ and $140-5 \mathrm{p}^{76}$. Liang et al. also suggested that miR-140 targets MMP-13 as a result of $17-\beta$-estradiol (E2) stimulation increasing miR$140-5 p^{77}$. Liu et al. demonstrated that miR-136 might also target the MMP-13 3'-UTR in competition with a potential sponge circular RNA, circRNA-CER, although more evidence of these interactions is needed ${ }^{78}$. In a more detailed study, Meng et al. reported that miR-320 is regulated by $\mathrm{IL}-1$ signalling and represses $M M P 13$ expression directly ${ }^{79}$. Consistent with previous studies, miR-320 is also upregulated during chondrogenesis which might contribute to the suppression of MMP13 expression $^{79}$. Two long non-coding RNAs-lncRNA-CIR (RP11-162L10.1) and GAS5-have also recently been shown to regulate the expression level of $M M P 13$, although again further work is necessary to establish their mechanisms of action $^{80,81}$.

\section{Recent advances in MMP-13 protein regulation and inhibition}

The MMP-13 protein is $54 \mathrm{kDa}$ in size and has catalytic, linker and haemopexin domains. As described above, MMP-13 is one of only three soluble MMPs capable of triple-helical collagen cleavage with a strong preference for type II collagen ${ }^{82}$, although the mechanism by which this happens is not yet fully elucidated. In recent years, crystal structures have revealed the mode of binding for the related collagenase, MMP- ${ }^{83,84}$, and the catalytic and haemopexin domain play essential roles in the interaction. Furthermore, novel exosites on MMP-13 which have provided insight into the mode of collagen binding have now been identified ${ }^{85}$.

Regulation of MMP-13 at the protein level is multifaceted and includes activation, endocytosis and inhibition. The activation of proMMPs is of central importance in effecting cartilage degradation ${ }^{86-89}$. An exciting field of research seeks to distinguish MMP-13 activity from total protein by using specific activity-based probes. Such probes can detect MMP-13 activity in mice that have undergone DMM surgery and could provide a useful tool for detecting early changes in OA prior to significant histological damage $\mathrm{e}^{90,91}$.

Identifying novel physiological activators of MMP-13 should be an important area of research, and the likely importance of serine proteinases in these processes was recently reviewed ${ }^{92}$. MMP-13 can be activated directly by plasmin ${ }^{93}$, and although this proteinase is not expressed by chondrocytes ${ }^{94}$, diffusion from the synovium should not be discounted. In vivo activators of MMP-13 may include other MMPs such as MMP-3 or MMP-14 ${ }^{82,95}$. Indeed, the membrane-anchored serine proteinases matriptase and hepsin can both induce collagen release from human OA cartilage and, although neither can directly activate MMP-13, both are potent activators of MMP-3 $3^{94,96}$ and thus indirectly MMP-13. Jackson et al. demonstrated an increase in MMP-13 activity in cultures treated with activated protein C, although the authors suggested that this likely acts through an intermediary within OA cartilage matrix ${ }^{97}$.

The major endogenous inhibitors for metalloproteinases are the tissue inhibitors of metalloproteases (TIMPs). Four members are expressed in human tissues (TIMP1-4), and each exhibits a two-domain structure: an $\mathrm{N}$-terminal domain containing a 'wedge-shaped' ridge which binds to the metalloproteinase active site and a C-terminal domain which interacts with the haemopexin domain ${ }^{98}$. TIMP-3 in particular has been ascribed a chondroprotective role in cartilage, and aged mice deficient in this inhibitor exhibit increased cartilage collagen destruction ${ }^{99}$. TIMPs can be structurally engineered, and Lim et al. generated mutants of TIMP-3 which selectively inhibit a disintegrin and metalloproteinase with thrombospondin motifs 4 (ADAMTS-4) and ADAMTS $-5^{100}$. This may represent a strategy to harness the natural potency of TIMPs whilst improving selectivity for particular metalloproteinases.

In recent years, our understanding of the importance of endocytosis in regulating cartilage metalloproteinase levels has grown significantly. Low-density lipoprotein-related protein-1 
(LRP-1) functions as an endocytic receptor, which has been shown to have a significant effect on the levels of metalloproteinases and their inhibitors in cartilage. Indeed, ADAMTS-5, ADAMTS-4, TIMP-3 and MMP-13 are endocytosed by LRP-1 in chondrocytes ${ }^{101-105}$. Interestingly, MMP-13 bound LRP-1 via its haemopexin domain at a site distinct to ADAMTS-5, ADAMTS-4 and TIMP3, which permits co-endocytosis with these proteins ${ }^{101}$. Intriguingly, proMMP-13 and active MMP-13 bound to LRP-1 with similar dissociation constants. These data suggest that selected metalloproteinases, including MMP-13, are constitutively produced by chondrocytes but their rapid endocytosis by LRP-1 may explain why they are difficult to detect in healthy adult tissue ${ }^{101}$. LRP-1 shedding is increased in $\mathrm{OA}^{103}$, a process which involves ADAM17 and MMP-14 ${ }^{104}$, inhibition of which may represent a novel targeting strategy to reduce proteinase levels (such as those of MMP-13) in cartilage. Interestingly, a different therapeutic strategy involves reducing TIMP-3 binding to LRP-1, thereby increasing its level in the ECM. TIMP-3 mutants engineered to resist endocytosis have prolonged chondroprotective activity ${ }^{106}$, and the chemical suramin, which binds to TIMP-3 and reduces its capacity to be endocytosed, has chondroprotective effects ${ }^{107}$.

As mentioned, selective MMP inhibition is a challenge due to the significant overlap of active site structural architecture. In the 1990s, a flurry of activity led to the development of MMP inhibitors for the treatment of cancer metastasis, which ultimately failed because of the broad range of MMPs which they targeted ${ }^{92}$. In fact, it is now recognised that a significant number of MMPs are considered 'anti-targets' ${ }^{19}$ which must be avoided. The central importance of MMP-13 in the irreversible destruction of cartilage collagen means that it remains an attractive target for the treatment of OA, and new waves of inhibitors demonstrate remarkably improved selectivity when compared with the initial failed compounds. Indeed, many make use of the unusually large $\mathrm{S}^{\prime}$ pocket in the MMP-13 active site, which is distinct amongst the MMPs. The latest advances and approaches in MMP-13 medicinal chemistry were recently reviewed elsewhere ${ }^{108}$. Of course, even very specific inhibitors could have adverse effects because MMP-13 has functions outside of cartilage (for instance, during wound healing) ${ }^{13}$.

Other methods outside of traditional small-molecule inhibition have also been explored. An interesting study by Naito et al. demonstrated the development of a novel MMP-13 neutralising antibody, which selectively binds the active MMP-13 and is highly selective over other MMPs ${ }^{109}$. Antibody technology is an effective method to selectively target MMP-13 and reduce offtarget effects against other MMPs. Although antibody therapeutics have disadvantages over conventional small-molecule inhibitors (such as limited administration routes, difficulties penetrating cartilage, and expense), they have proven successful for the treatment of rheumatoid arthritis and are being explored for other targets in $\mathrm{OA}^{110}$. We hypothesise that there is likely to be significant research in this area with respect to MMP-13 in the coming years.

\section{Conclusions and future directions}

In our view, MMPs, and especially the collagenases, are tractable targets for preventing cartilage destruction in OA. Although the initial wave of MMP inhibitors failed in the clinic, there does appear to be renewed interest both in terms of direct inhibition but also in targeting mechanisms of regulation as a therapeutic target, be it via activation or gene expression mechanisms. Here, we have summarised recent work examining such regulatory mechanisms and focussed on transcriptional and post-translational MMP-13 regulation.

In terms of gene regulation, we expect new discoveries on the mechanism of MMP regulation to be aided by the improvement and application of both genome-wide and single-cell technologies. Our current understanding of the role of DNA methylation in MMP-13 regulation, for example, has been limited either by the use of low-throughput technologies (such as pyrosequencing) to examine short genomic regions or by the limited presence of MMP-13 locus probes on current array-based systems. Whole genome methylation analysis will facilitate much better coverage of the MMP genomic locus, hopefully identifying important regulatory regions in disease. Similarly, our knowledge of the chromatin status of chondrocytes has largely been imputed from other cells and tissues, based on data from large-scale consortia. ChIP-seq and ATAC-seq data from chondrocytes will likely provide insight into identifying key regulatory genomic features, and systematic genomic editing (using, for example, CRISPR/Cas9) will be needed to characterise the importance of these regions. Deactivated Cas9-fusion proteins are also proving invaluable in confirming the gene regulatory function of genomic loci. As with all regulatory networks, these complex datasets will require integrated bioinformatics tools to fully delineate the mechanisms involved in MMP regulation and such a systems approach is beginning to identify underlying mechanisms involved in age-related changes in musculoskeletal tissues ${ }^{111}$. Interestingly, examining correlative gene expression programmes may also lead to further understanding of gene regulatory networks; with this in mind, SkeletalVis provides an accessible data portal for comparing cross-species skeletal transcriptomics data ${ }^{112}$.

Post-translational regulation of MMP-13 may also represent an attractive approach. Identifying crucial activators of MMP-13 (or indeed other MMPs upstream of MMP-13) is important, as such proteinases may represent a novel and indirect method to limit collagen degradation. Proteinases do not act in isolation but rather are the culmination of complex proteolytic cascades, of which MMP-13 is the final effector. The evolving field of 'degradomics' will likely prove essential for the deconvolution of such cascades and lead to the identification of novel proteinases or indeed new substrates for previously welldescribed proteinases. The importance of endocytosis is also becoming clear. Catabolic metalloproteinases (including MMP-13) which are not removed efficiently from the extracellular milieu by endocytic mechanisms are damaging, and efforts to 'boost' these mechanisms represent an interesting approach to reduce the proteolytic burden on cartilage. 
MMP-13 expression and function are not limited solely to cartilage; thus, systemic delivery mechanisms to regulate MMP-13 activity, even with very specific inhibitors, may still elicit adverse effects. One intriguing possibility is delivery of anti-inflammatory or immunomodulatory compounds linked to other moieties that are released upon MMP-mediated cleavage $^{113}$. For example, Vessillier et al. used immunomodulatory peptides fused via an MMP cleavage site to the latencyassociated peptide of TGF- $\beta 1$ to limit inflammation in the collagen-induced arthritis model ${ }^{114}$. This system elegantly uses pathologically active MMPs as the release mechanism, selectively targeting the biologically active compound to the required tissue, thus theoretically allowing systemic delivery. Interest also remains in intra-articular injection as a delivery route for disease-modifying OA treatments but this has a number of shortcomings mainly pertaining to inadequate drug delivery because of the biochemical nature of cartilage ${ }^{115}$. However, improvements in intra-articular delivery have been reported with the advent of nanoparticles or nanocarriers. For example, nanoparticlebased intra-articular delivery of siRNA against NF- $\kappa B$ (p65 and p100) was non-immunogenic and cartilage-penetrant and reduced chondrocyte death following a non-invasive murine model of joint injury ${ }^{116}$. Similarly, a single intra-articular injection an IGF1-conjugated nanocarrier reduced cell and aggrecan loss in a rat surgical model of $\mathrm{OA}^{117}$. Thus, a range of options are emerging to effectively target cartilage-derived MMP-13 activity specifically. Finally, although this review has focussed specifically on cartilage and mainly on MMP-13, many of the advancements are applicable to the large repertoire of metalloproteinases and the many development and diseaserelated pathways in which they play a role ${ }^{118}$.

\section{Grant information}

This work was supported by the Medical Research Council (MRC) and Arthritis Research UK as part of the MRC-Arthritis Research UK Centre for Integrated Research into Musculoskeletal Ageing (grants JXR 10641 and MR/P020941/1), Arthritis Research UK (grant 20199), the JGW Patterson Foundation, and the Dunhill Medical Trust.

The funders had no role in study design, data collection and analysis, decision to publish, or preparation of the manuscript.
1. Arthritis Research UK: State of Musculoskeletal Health 2018: Arthritis and othe musculoskeletal conditions in numbers. 2018. Reference Source

2. Jubb RW, Fell HB: The breakdown of collagen by chondrocytes. J Pathol. 1980; 130(3): 159-67.

PubMed Abstract | Publisher Full Text

3. Rowan AD, Litherland GJ, Hui W, et al:: Metalloproteases as potential therapeutic targets in arthritis treatment. Expert Opin Ther Targets. 2008; 12(1): 1-18. PubMed Abstract | Publisher Full Text

4. Billinghurst RC, Dahlberg L, lonescu M, et al:: Enhanced cleavage of type II collagen by collagenases in osteoarthritic articular cartilage. J Clin Invest. 1997: 99(7): 1534-45.

PubMed Abstract | Publisher Full Text | Free Full Text

5. Dahlberg L, Billinghurst RC, Manner P, et al:: Selective enhancement of collagenase-mediated cleavage of resident type II collagen in cultured osteoarthritic cartilage and arrest with a synthetic inhibitor that spares collagenase 1 (matrix metalloproteinase 1). Arthritis Rheum. 2000; 43(3): 673-82. PubMed Abstract | Publisher Full Text

6. Dejica VM, Mort JS, Laverty S, et al.: Increased type II collagen cleavage by cathepsin $\mathrm{K}$ and collagenase activities with aging and osteoarthritis in human articular cartilage. Arthritis Res Ther. 2012; 14(3): R113.

PubMed Abstract | Publisher Full Text | Free Full Text

7. Gauci SJ, Stanton H, Little CB, et al.: Proteoglycan and Collagen Degradation in Osteoarthritis. In: Grässel S, Aszódi A, editors. Cartilage. New York, NY: Springer Berlin Heidelberg; 2017; 41-61.

Publisher Full Text

8. F Little CB, Barai A, Burkhardt D, et al:: Matrix metalloproteinase 13-deficient mice are resistant to osteoarthritic cartilage erosion but not chondrocyte hypertrophy or osteophyte development. Arthritis Rheum. 2009; 60(12): 3723-33. PubMed Abstract | Publisher Full Text | Free Full Text | F1000 Recommendation

9. Neuhold LA, Killar L, Zhao W, et al.: Postnatal expression in hyaline cartilage of constitutively active human collagenase-3 (MMP-13) induces osteoarthritis in mice. J Clin Invest. 2001; 107(1): 35-44.

PubMed Abstract | Publisher Full Text | Free Full Text

10. Inada $\mathrm{M}$, Wang $\mathrm{Y}$, Byrne $\mathrm{MH}$, et al:: Critical roles for collagenase-3 (Mmp13) in development of growth plate cartilage and in endochondral ossification. Proc Natl Acad Sci U S A. 2004; 101(49): 17192-7.

PubMed Abstract | Publisher Full Text | Free Full Text

11. Stickens D, Behonick DJ, Ortega N, et al:: Altered endochondral bone development in matrix metalloproteinase 13-deficient mice. Development. 2004;
131(23): 5883-95

PubMed Abstract | Publisher Full Text | Free Full Text

12. Quillard T, Araújo HA, Franck $G$, et al: Matrix metalloproteinase-13 predominates over matrix metalloproteinase-8 as the functional interstitial collagenase in mouse atheromata. Arterioscler Thromb Vasc Biol. 2014; 34(6) 1179-86.

PubMed Abstract | Publisher Full Text | Free Full Text

13. Hattori N, Mochizuki S, Kishi K, et al:: MMP-13 plays a role in keratinocyte migration, angiogenesis, and contraction in mouse skin wound healing. $\mathrm{Am} J$ Pathol. 2009; 175(2): 533-46.

PubMed Abstract | Publisher Full Text | Free Full Text

14. Patel AC, McAlister WH, Whyte MP: Spondyloepimetaphyseal dysplasia: clinical and radiologic investigation of a large kindred manifesting autosomal dominant inheritance, and a review of the literature. Medicine (Baltimore). 1993; 72(5): 326-42.

PubMed Abstract | Publisher Full Text

15. Kennedy AM, Inada M, Krane SM, et al.: MMP13 mutation causes spondyloepimetaphyseal dysplasia, Missouri type $\left(\mathrm{SEMD}_{\text {мо }}\right)$. J Clin Invest. 2005; 115(10): 2832-42.

PubMed Abstract | Publisher Full Text | Free Full Text

16. Bonafe L, Cormier-Daire V, Hall C, et al:: Nosology and classification of genetic skeletal disorders: 2015 revision. Am J Med Genet A. 2015; 167A(12): 2869-92. PubMed Abstract | Publisher Full Text

17. Shiomi T, Lemaître V, D'Armiento J, et al:: Matrix metalloproteinases, a disintegrin and metalloproteinases, and a disintegrin and metalloproteinases with thrombospondin motifs in non-neoplastic diseases. Pathol Int. 2010; 60(7): with throm $477-96$.

PubMed Abstract | Publisher Full Text | Free Full Text

18. Knäuper V, Cowell S, Smith B, et al:: The role of the C-terminal domain of human collagenase-3 (MMP-13) in the activation of procollagenase-3, substrate specificity, and tissue inhibitor of metalloproteinase interaction. $J$ Biol Chem. 1997; 272(12): 7608-16. 1997; 272(12): 7608-16.
PubMed Abstract | Publisher Full Text

19. Dufour A, Overall CM: Missing the target: matrix metalloproteinase antitargets in inflammation and cancer. Trends Pharmacol Sci. 2013; 34(4): 233-42. PubMed Abstract | Publisher Full Text

20. Fanjul-Fernández M, Folgueras AR, Cabrera S, et al:: Matrix metalloproteinases: evolution, gene regulation and functional analysis in mouse models. Biochim Biophys Acta. 2010; 1803(1): 3-19.

PubMed Abstract | Publisher Full Text 
21. Yan C, Boyd DD: Regulation of matrix metalloproteinase gene expression. J Cell Physiol. 2007; 211(1): 19-26. PubMed Abstract | Publisher Full Text

22. Benbow $U$, Brinckerhoff $C E$ : The AP-1 site and MMP gene regulation: what is all the fuss about? Matrix Biol. 1997; 15(8-9): 519-26. PubMed Abstract | Publisher Full Text

23. Catterall JB, Carrère $S$, Koshy PJ, et al: Synergistic induction of matrix metalloproteinase 1 by interleukin-1alpha and oncostatin $M$ in human chondrocytes involves signal transducer and activator of transcription and activator protein 1 transcription factors via a novel mechanism. Arthritis Rheum. 2001; 44(10): 2296-310.

PubMed Abstract | Publisher Full Text

24. Mengshol JA, Vincenti MP, Brinckerhoff CE: IL-1 induces collagenase-3 (MMP13) promoter activity in stably transfected chondrocytic cells: requirement for Runx-2 and activation by p38 MAPK and JNK pathways. Nucleic Acids Res. 2001; 29(21): 4361-72.

PubMed Abstract | Publisher Full Text | Free Full Text

25. Benderdour M, Tardif G, Pelletier JP, et al:: Interleukin 17 (IL-17) induces collagenase-3 production in human osteoarthritic chondrocytes via AP-1 dependent activation: differential activation of AP-1 members by IL-17 and IL-1beta. J Rheumatol. 2002; 29(6): 1262-72.

PubMed Abstract

26. Koshy PJ, Henderson N, Logan C, et al:: Interleukin 17 induces cartilage collagen breakdown: novel synergistic effects in combination with proinflammatory cytokines. Ann Rheum Dis. 2002; 61(8): 704-13. PubMed Abstract | Publisher Full Text | Free Full Text

27. Liacini A, Sylvester J, Li WQ, et al:: Induction of matrix metalloproteinase-13 gene expression by TNF-alpha is mediated by MAP kinases, AP-1, and NFkappaB transcription factors in articular chondrocytes. Exp Cell Res. 2003; 288(1): 208-17.

PubMed Abstract | Publisher Full Text

28. Vincenti MP, Brinckerhoff CE: Transcriptional regulation of collagenase (MMP-1, MMP-13) genes in arthritis: integration of complex signaling pathways for the recruitment of gene-specific transcription factors. Arthritis Res. 2002 4(3): 157-64.

PubMed Abstract | Publisher Full Text | Free Full Text

29. Rowan $A D$, Young DA: Collagenase gene regulation by pro-inflammatory cytokines in cartilage. Front Biosci. 2007; 12: 536-50.

PubMed Abstract | Publisher Full Text

30. Chan CM, Macdonald CD, Litherland GJ, et al:: Cytokine-induced MMP13 Expression in Human Chondrocytes Is Dependent on Activating Transcription Factor 3 (ATF3) Regulation. J Biol Chem. 2017; 292(5): 1625-36. PubMed Abstract | Publisher Full Text | Free Full Text

31. Baker J, Falconer AMD, Wilkinson DJ, et al:: Protein kinase D3 modulates MMP1 and MMP13 expression in human chondrocytes. PLoS One. 2018; 13(4): e0195864

PubMed Abstract | Publisher Full Text | Free Full Text

32. Zhang Q, Hui W, Litherland GJ, et al:: Differential Toll-like receptor-dependent collagenase expression in chondrocytes. Ann Rheum Dis. 2008; 67(11): 1633-41. PubMed Abstract | Publisher Full Text

33. Ding L, Guo D, Homandberg GA: Fibronectin fragments mediate matrix metalloproteinase upregulation and cartilage damage through proline rich tyrosine kinase 2, c-src, NF-kappaB and protein kinase Cdelta. Osteoarthritis Cartilage. 2009; 17(10): 1385-92.

PubMed Abstract | Publisher Full Tex

34. Radwan M, Gavriilidis C, Robinson JH, et al: Matrix metalloproteinase 13 expression in response to double-stranded RNA in human chondrocytes. Arthritis Rheum. 2013; 65(5): 1290-301.

PubMed Abstract | Publisher Full Text

35. Gilbert SJ, Blain EJ, Al-Sabah A, et al:: Protein kinase R plays a pivotal role in oncostatin $\mathrm{M}$ and interleukin-1 signalling in bovine articular cartilage chondrocytes. Eur Cell Mater. 2012; 23: 41-57. PubMed Abstract | Publisher Full Text

36. $\mathrm{F} \mathrm{Ma} \mathrm{CH}, \mathrm{Wu} \mathrm{CH}$, Jou IM, et al.: PKR activation causes inflammation and MMP-13 secretion in human degenerated articular chondrocytes. Redox Biol. 2018; 14: 72-81.

PubMed Abstract | Publisher Full Text | Free Full Text | F1000 Recommendation

37. Burrage PS, Schmucker AC, Ren $\mathrm{Y}$, et al:: Retinoid $\mathrm{X}$ receptor and peroxisome proliferator-activated receptor-gamma agonists cooperate to inhibit matrix metalloproteinase gene expression. Arthritis Res Ther. 2008; 10(6): R139. PubMed Abstract | Publisher Full Text | Free Full Text

38. Gil J, García MA, Gomez-Puertas P, et al:: TRAF family proteins link PKR with NF-kappa B activation. Mol Cell Biol. 2004; 24(10): 4502-12. PubMed Abstract | Publisher Full Text | Free Full Text

39. $\mathrm{F} K \mathrm{Kim} \mathrm{JH}$, Jeon J, Shin M, et al.: Regulation of the catabolic cascade in osteoarthritis by the zinc-ZIP8-MTF1 axis. Cell. 2014; 156(4): 730-43. PubMed Abstract | Publisher Full Text | F1000 Recommendation

40. Yammani RR, Loeser RF: Brief report: stress-inducible nuclear protein 1 regulates matrix metalloproteinase 13 expression in human articular chondrocytes. Arthritis Rheumatol. 2014; 66(5): 1266-71. PubMed Abstract | Publisher Full Text | Free Full Text

41. F Loeser RF, Olex AL, McNulty MA, et al.: Microarray analysis reveals age-related differences in gene expression during the development of osteoarthritis in mice. Arthritis Rheum. 2012; 64(3): 705-17. PubMed Abstract | Publisher Full Text | Free Full Text | F1000 Recommendation

2. Tuckermann JP, Pittois K, Partridge NC, et al: Collagenase-3 (MMP-13) and integral membrane protein 2a (Itm2a) are marker genes of chondrogenic/ osteoblastic cells in bone formation: Sequential temporal, and spatial expression of Itm2a, alkaline phosphatase, MMP-13, and osteocalcin in the mouse. J Bone Miner Res. 2000; 15(7): 1257-65.

PubMed Abstract | Publisher Full Tex

43. F Bianchi A, Guibert M, Cailotto F, et al.: Fibroblast Growth Factor 23 drives MMP13 expression in human osteoarthritic chondrocytes in a Klothoindependent manner. Osteoarthritis Cartilage. 2016; 24(11): 1961-9. PubMed Abstract | Publisher Full Text | F1000 Recommendation

44. F Chuchana P, Mausset-Bonnefont AL, Mathieu M, et al.: Secreted $\alpha$-Klotho maintains cartilage tissue homeostasis by repressing NOS2 and ZIP8-MMP13 catabolic axis. Aging (Albany NY). 2018; 10(6): 1442-53.

PubMed Abstract | Publisher Full Text | Free Full Text | F1000 Recommendation

45. Doi S, Zou Y, Togao O, et al:: Klotho inhibits transforming growth factor-beta1 (TGF-beta1) signaling and suppresses renal fibrosis and cancer metastasis in mice. J Biol Chem. 2011; 286(10): 8655-65.

PubMed Abstract | Publisher Full Text | Free Full Text

46. Hosaka Y, Saito T, Sugita S, et al.: Notch signaling in chondrocytes modulates endochondral ossification and osteoarthritis development. Proc Natl Acad SCi U S A. 2013; 110(5): 1875-80.

PubMed Abstract | Publisher Full Text | Free Full Text

47. F Sugita S, Hosaka Y, Okada K, et al:: Transcription factor Hes1 modulates osteoarthritis development in cooperation with calcium/calmodulin-dependent protein kinase 2. Proc Natl Acad Sci U S A. 2015; 112(10): 3080-5.

PublMed Abstract | Publisher Full Text | Free Full Text | F1000 Recommendation

48. Hojo H, McMahon AP, Ohba S: An Emerging Regulatory Landscape for Skeletal Development. Trends Genet. 2016; 32(12): 774-87.

PubMed Abstract | Publisher Full Text | Free Full Text

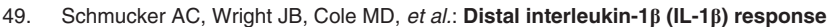
element of human matrix metalloproteinase-13 (MMP-13) binds activator protein 1 (AP-1) transcription factors and regulates gene expression. $J$ BiO Chem. 2012; 287(2): 1189-97.

PubMed Abstract | Publisher Full Text | Free Full Text

50. F Meyer MB, Benkusky NA, Pike JW: Selective Distal Enhancer Control of the Mmp13 Gene Identified through Clustered Regularly Interspaced Short Palindromic Repeat (CRISPR) Genomic Deletions. J Biol Chem. 2015; 290(17): 11093-107.

PubMed Abstract | Publisher Full Text | Free Full Text | F1000 Recommendation

51. F Meyer MB, Benkusky NA, Onal M, et al: Selective regulation of Mmp13 by $1,25(\mathrm{OH})_{2} \mathrm{D}_{3}, \mathrm{PTH}$, and Osterix through distal enhancers. J Steroid Biochem Mol Biol. 2016; 164: 258-64.

PubMed Abstract | Publisher Full Text | Free Full Text | F1000 Recommendation

52. F Roadmap Epigenomics Consortium, Kundaje A, Meuleman W, et al:: Integrative analysis of 111 reference human epigenomes. Nature. 2015; 518(7539): 317-30. PubMed Abstract | Publisher Full Text | Free Full Text | F1000 Recommendation

53. F Liu Y, Chang JC, Hon CC, et al.: Chromatin accessibility landscape of articular knee cartilage reveals aberrant enhancer regulation in osteoarthritis. Sci Rep. 2018; 8(1): 15499.

PubMed Abstract | Publisher Full Text | Free Full Text | F1000 Recommendation

54. Hui W, Cawston T, Rowan AD: Transforming growth factor beta 1 and insulinlike growth factor 1 block collagen degradation induced by oncostatin $\mathrm{M}$ in combination with tumour necrosis factor alpha from bovine cartilage. Ann Rheum Dis. 2003: 62(2): 172-4.

PubMed Abstract | Publisher Full Text | Free Full Text

55. Ahmad R, Qureshi HY, El Mabrouk M, et al:: Inhibition of interleukin 1-induced matrix metalloproteinase 13 expression in human chondrocytes by interferon gamma. Ann Rheum Dis. 2007; 66(6): 782-9.

PubMed Abstract | Publisher Full Text | Free Full Tex

56. F Santoro A, Conde J, Scotece M, et al:: SERPINE2 Inhibits IL-1 $\alpha$-Induced MMP-13 Expression in Human Chondrocytes: Involvement of ERK/NF-KB/AP-1 Pathways. PLoS One. 2015; 10(8): e0135979.

PubMed Abstract | Publisher Full Text | Free Full Text | F1000 Recommendation

57. F Bleuel J, Zaucke F, Brüggemann GP, et al:: Effects of cyclic tensile strain on chondrocyte metabolism: a systematic review. PLoS One. 2015; 10(3): e0119816.

PubMed Abstract | Publisher Full Text | Free Full Text | F1000 Recommendation

58. Sun HB: Mechanical loading, cartilage degradation, and arthritis. Ann NY Acad Sci. 2010; 1211: 37-50

PubMed Abstract | Publisher Full Text

59. Leong DJ, Li YH, Gu XI, et al.: Physiological loading of joints prevents cartilage degradation through CITED2. FASEB J. 2011; 25(1): 182-91.

PubMed Abstract | Publisher Full Text | Free Full Text

60. $\mathrm{F}$ He Z, Leong DJ, Zhuo Z, et al.: Strain-induced mechanotransduction through primary cilia, extracellular ATP, purinergic calcium signaling, and ERK1/2 transactivates CITED2 and downregulates MMP-1 and MMP-13 gene expression in chondrocytes. Osteoarthritis Cartilage. 2016; 24(5): 892-901. PubMed Abstract | Publisher Full Text | F1000 Recommendation 
61. Barter MJ, Bui C, Young DA: Epigenetic mechanisms in cartilage and osteoarthritis: DNA methylation, histone modifications and microRNAs. Osteoarthritis Cartilage. 2012; 20(5): 339-49.

PubMed Abstract | Publisher Full Text

62. Young DA, Lakey RL, Pennington CJ, et al.: Histone deacetylase inhibitors modulate metalloproteinase gene expression in chondrocytes and block cartilage resorption. Arthritis Res Ther. 2005; 7(3): R503-12. PubMed Abstract | Publisher Full Text | Free Full Text

63. F Culley KL, Hui W, Barter MJ, et al:: Class I histone deacetylase inhibition modulates metalloproteinase expression and blocks cytokine-induced cartilage degradation. Arthritis Rheum. 2013; 65(7): 1822-30. PubMed Abstract | Publisher Full Text | F1000 Recommendation

64. F Elayyan J, Lee EJ, Gabay O, et al.: LEF1-mediated MMP13 gene expression is repressed by SIRT1 in human chondrocytes. FASEB J. 2017; 31(7): 3116-25. PubMed Abstract | Publisher Full Text | F1000 Recommendation

65. Miyamoto $Y$, Mabuchi A, Shi D, et al:: A functional polymorphism in the 5' UTR of GDF5 is associated with susceptibility to osteoarthritis. Nat Genet. 2007; 39(4): $529-33$.

PubMed Abstract | Publisher Full Text

66. F Chen H, Capellini TD, Schoor M, et al:: Heads, Shoulders, Elbows, Knees, and Toes: Modular Gdf5 Enhancers Control Different Joints in the Vertebrate Skeleton. PLoS Genet. 2016; 12(11): e1006454.

PubMed Abstract | Publisher Full Text | Free Full Text | F1000 Recommendation

67. Enochson L, Stenberg J, Brittberg M, et al: GDF5 reduces MMP13 expression in human chondrocytes via DKK1 mediated canonical Wnt signaling inhibition. Osteoarthritis Cartilage. 2014; 22(4): 566-77. PubMed Abstract | Publisher Full Text

68. F Ratnayake M, Plöger F, Santibanez-Koref M, et al.: Human chondrocytes respond discordantly to the protein encoded by the osteoarthritis susceptibility gene GDF5. PLoS One. 2014; 9(1): e86590. PubMed Abstract | Publisher Full Text | Free Full Text | F1000 Recommendation

69. Bui C, Barter MJ, Scott JL, et al:: cAMP response element-binding (CREB) recruitment following a specific $\mathrm{CpG}$ demethylation leads to the elevated expression of the matrix metalloproteinase 13 in human articular chondrocytes and osteoarthritis. FASEB J. 2012; 26(7): 3000-11. PubMed Abstract | Publisher Full Text

70. F Hashimoto K, Otero M, Imagawa K, et al:: Regulated transcription of human matrix metalloproteinase 13 (MMP13) and interleukin-1ß (IL1B) genes in chondrocytes depends on methylation of specific proximal promoter $\mathrm{CpG}$ sites. J Biol Chem. 2013; 288(14): 10061-72. sites. J Biol Chem. 2013; 288(14): 10061-72.
PubMed Abstract | Publisher Full Text | Free Full Text | F1000 Recommendation

71. F Takahashi A, de Andrés MC, Hashimoto K, et al:: DNA methylation of the RUNX2 P1 promoter mediates MMP13 transcription in chondrocytes. Sci Rep. 2017; 7(1): 7771

PubMed Abstract | Publisher Full Text | Free Full Text | F1000 Recommendation

72. F Rushton MD, Reynard LN, Barter MJ, et al:: Characterization of the cartilage DNA methylome in knee and hip osteoarthritis. Arthritis Rheumatol. 2014; 66(9): 2450-60.

PubMed Abstract | Publisher Full Text | Free Full Text | F1000 Recommendation

73. F Alvarez-Garcia O, Fisch KM, Wineinger NE, et al.: Increased DNA Methylation and Reduced Expression of Transcription Factors in Human Osteoarthritis Cartilage. Arthritis Rheumatol. 2016; 68(8): 1876-86.

PubMed Abstract | Publisher Full Text | Free Full Text | F1000 Recommendation

74. Le LT, Swingler TE, Clark IM: Review: the role of microRNAs in osteoarthritis and chondrogenesis. Arthritis Rheum. 2013; 65(8): 1963-74. PubMed Abstract | Publisher Full Text

75. F Agarwal V, Bell GW, Nam JW, et al:: Predicting effective microRNA target sites in mammalian mRNAs. eLife. 2015; 4: e05005. PubMed Abstract | Publisher Full Text | Free Full Text | F1000 Recommendation

76. $\mathrm{F}$ Chou $\mathrm{CH}$, Shrestha S, Yang CD, et al.: miRTarBase update 2018: a resource for experimentally validated microRNA-target interactions. Nucleic Acids Res. 2018; 46(D1): D296-D302.

PubMed Abstract | Publisher Full Text | Free Full Text | F1000 Recommendation

77. F Liang $\mathrm{Y}$, Duan L, Xiong J, et al.: E2 regulates MMP-13 via targeting miR-140 in IL-1 $\beta$-induced extracellular matrix degradation in human chondrocytes. Arthritis Res Ther. 2016; 18(1): 105.

PubMed Abstract | Publisher Full Text | Free Full Text | F1000 Recommendation

78. Liu Q, Zhang X, Hu X, et al:: Circular RNA Related to the Chondrocyte ECM Regulates MMP13 Expression by Functioning as a MiR-136 'Sponge' in Human Cartilage Degradation. Sci Rep. 2016; 6: 22572.

PubMed Abstract | Publisher Full Text | Free Full Text

79. F Meng F, Zhang Z, Chen W, et al:: MicroRNA-320 regulates matrix metalloproteinase-13 expression in chondrogenesis and interleukin-16induced chondrocyte responses. Osteoarthritis Cartilage. 2016; 24(5): 932-41. PubMed Abstract | Publisher Full Text | F1000 Recommendation

80. $F$ Liu $Q$, Zhang $X$, Dai $L$, et al.: Long noncoding $R N A$ related to cartilage injury promotes chondrocyte extracellular matrix degradation in osteoarthritis. Arthritis Rheumatol. 2014; 66(4): 969-78.

PubMed Abstract | Publisher Full Text | F1000 Recommendation
81. Song J, Ahn C, Chun $\mathrm{CH}$, et al:: A long non-coding RNA, GAS5, plays a critical role in the regulation of miR-21 during osteoarthritis. J Orthop Res. 2014; 32(12): 1628-35.

PubMed Abstract | Publisher Full Text

82. Knäuper V, López-Otin C, Smith B, et al:: Biochemical characterization of human collagenase-3. J Biol Chem. 1996; 271(3): 1544-50.

PubMed Abstract | Publisher Full Text

83. Manka SW, Carafoli F, Visse R, et al:: Structural insights into triple-helical collagen cleavage by matrix metalloproteinase 1. Proc Natl Acad Sci U S A. 2012; 109(31): 12461-6.

PubMed Abstract | Publisher Full Text | Free Full Text

84. Bertini I, Calderone V, Cerofolini L, et al.: The catalytic domain of MMP-1 studied through tagged lanthanides. FEBS Lett. 2012; 586(5): 557-67.

PubMed Abstract | Publisher Full Text

85. Stura $E A$, Visse $R$, Cuniasse $P$, et al:: Crystal structure of full-length human collagenase 3 (MMP-13) with peptides in the active site defines exosites in the catalytic domain. FASEB J.2013; 27(11): 4395-405.

PubMed Abstract | Publisher Full Text | Free Full Text

86. Milner JM, Elliott SF, Cawston TE: Activation of procollagenases is a key control point in cartilage collagen degradation: interaction of serine and metalloproteinase pathways. Arthritis Rheum. 2001; 44(9): 2084-96. PubMed Abstract | Publisher Full Text

87. Milner JM, Rowan AD, Elliott SF, et al:: Inhibition of furin-like enzymes blocks interleukin-1alpha/oncostatin M-stimulated cartilage degradation. Arthritis Rheum. 2003; 48(4): 1057-66.

PubMed Abstract | Publisher Full Text

88. Milner JM, Rowan AD, Cawston TE, et al:: Metalloproteinase and inhibitor expression profiling of resorbing cartilage reveals pro-collagenase activation as a critical step for collagenolysis. Arthritis Res Ther. 2006; 8(5): R142. PubMed Abstract | Publisher Full Text | Free Full Text

89. Milner JM, Patel A, Rowan AD: Emerging roles of serine proteinases in tissue turnover in arthritis. Arthritis Rheum. 2008; 58(12): 3644-56.

PubMed Abstract | Publisher Full Text

90. Lim NH, Meinjohanns E, Meldal M, et al:: In vivo imaging of MMP-13 activity in the murine destabilised medial meniscus surgical model of osteoarthritis. Osteoarthritis Cartilage. 2014; 22(6): 862-8.

PubMed Abstract | Publisher Full Text

91. F Duro-Castano A, Lim NH, Tranchant I, et al.: In Vivo Imaging of MMP-13 Activity Using a Specific Polymer-FRET Peptide Conjugate Detects Early Osteoarthritis and Inhibitor Efficacy. Adv Funct Mater. 2018; 28(37): 1802738 Publisher Full Text | F1000 Recommendation

92. Wilkinson DJ, Arques MDC, Huesa C, et al:: Serine proteinases in the turnover of the cartilage extracellular matrix in the joint: implications for therapeutics. $\mathrm{Br} \mathrm{J}$ Pharmacol. 2019; 176(1): 38-51.

PubMed Abstract | Publisher Full Text | Free Full Text

93. Knäuper V, Will H, López-Otin C, et al:: Cellular mechanisms for human procollagenase-3 (MMP-13) activation. Evidence that MT1-MMP (MMP-14) and gelatinase a (MMP-2) are able to generate active enzyme. J Biol Chem. 1996; 271(29): 17124-31.

PubMed Abstract | Publisher Full Text

94. Milner JM, Patel A, Davidson RK, et al:: Matriptase is a novel initiator of cartilage matrix degradation in osteoarthritis. Arthritis Rheum. 2010; 62(7): 1955-66. PublMed Abstract | Publisher Full Text

95. Knäuper V, Bailey L, Worley JR, et al.: Cellular activation of proMMP-13 by MT1MMP depends on the C-terminal domain of MMP-13. FEBS Lett. 2002; 532(1-2): 127-30.

PubMed Abstract | Publisher Full Text

96. Wilkinson DJ, Desilets A, Lin H, et al:: The serine proteinase hepsin is an activator of pro-matrix metalloproteinases: molecular mechanisms and implications for extracellular matrix turnover. Sci Rep. 2017; 7(1): 16693. PubMed Abstract | Publisher Full Text | Free Full Text

97. Jackson MT, Moradi B, Smith MM, et al:: Activation of matrix metalloproteinases 2,9 , and 13 by activated protein $C$ in human osteoarthritic cartilage chondrocytes. Arthritis Rheumatol. 2014; 66(6): 1525-36.

PubMed Abstract | Publisher Full Text

98. Murphy G: Tissue inhibitors of metalloproteinases. Genome Biol. 2011; 12(11): 233.

PubMed Abstract | Publisher Full Text | Free Full Text

99. Sahebjam $S$, Khokha $R$, Mort JS: Increased collagen and aggrecan degradation with age in the joints of Timp3 ${ }^{\%}$ mice. Arthritis Rheum. 2007; 56(3): 905-9. PubMed Abstract | Publisher Full Text

100. Lim NH, Kashiwagi M, Visse R, et al:: Reactive-site mutants of N-TIMP-3 that selectively inhibit ADAMTS-4 and ADAMTS-5: biological and structural implications. Biochem J. 2010; 431(1): 113-22. PubMed Abstract | Publisher Full Text | Free Full Text

101. F Yamamoto $\mathrm{K}$, Okano $\mathrm{H}$, Miyagawa W, et al:: MMP-13 is constitutively produced in human chondrocytes and co-endocytosed with ADAMTS- 5 anc TIMP-3 by the endocytic receptor LRP1. Matrix Biol. 2016; 56: 57-73. PubMed Abstract | Publisher Full Text | Free Full Text | F1000 Recommendation

102. Yamamoto $\mathrm{K}$, Owen $\mathrm{K}$, Parker $\mathrm{AE}$, et al.: Low density lipoprotein receptorrelated protein 1 (LRP1)-mediated endocytic clearance of a disintegrin and metalloproteinase with thrombospondin motifs-4 (ADAMTS-4): functional 
differences of non-catalytic domains of ADAMTS-4 and ADAMTS- 5 in LRP1 binding. J Biol Chem. 2014; 289(10): 6462-74. PubMed Abstract | Publisher Full Text | Free Full Text

103. F Yamamoto K, Troeberg L, Scilabra SD, et al.: LRP-1-mediated endocytosis regulates extracellular activity of ADAMTS-5 in articular cartilage. FASEB J. 2013; 27(2): 511-21.

PubMed Abstract | Publisher Full Text | Free Full Text | F1000 Recommendation

104. F Yamamoto K, Santamaria S, Botkjaer KA, et al:: Inhibition of Shedding of Low-Density Lipoprotein Receptor-Related Protein 1 Reverses Cartilage Matrix Degradation in Osteoarthritis. Arthritis Rheumatol. 2017; 69(6): 1246-56. PubMed Abstract | Publisher Full Text | Free Full Text | F1000 Recommendation

105. Scilabra SD, Troeberg L, Yamamoto K, et al.: Differential regulation of extracellular tissue inhibitor of metalloproteinases-3 levels by cell membranebound and shed low density lipoprotein receptor-related protein 1. $J$ Biol Chem. 2013; 288(1): 332-42. PubMed Abstract | Publisher Full Text | Free Full Text

106. F Doherty CM, Visse R, Dinakarpandian D, et al.: Engineered Tissue Inhibitor of Metalloproteinases-3 Variants Resistant to Endocytosis Have Prolonged Chondroprotective Activity. J Biol Chem. 2016; 291(42): 22160-72. PubMed Abstract | Publisher Full Text | Free Full Text | F1000 Recommendation

107. F Chanalaris A, Doherty C, Marsden BD, et al.: Suramin Inhibits Osteoarthritic Cartilage Degradation by Increasing Extracellular Levels of Chondroprotective Tissue Inhibitor of Metalloproteinases 3. Mol Pharmacol. 2017; 92(4): 459-68. PubMed Abstract | Publisher Full Text | Free Full Text | F1000 Recommendation

108. Xie XW, Wan RZ, Liu ZP: Recent Research Advances in Selective Matrix Metalloproteinase-13 Inhibitors as Anti-Osteoarthritis Agents. ChemMedChem. 2017; 12(15): 1157-68. PubMed Abstract | Publisher Full Text

109. Naito S, Takahashi T, Onoda J, et al.: Development of a neutralizing antibody specific for the active form of matrix metalloproteinase-13. Biochemistry. 2012 51(44): 8877-84.

PubMed Abstract | Publisher Full Text

110. Zheng S, Hunter DJ, Xu J, et al.: Monoclonal antibodies for the treatment of osteoarthritis. Expert Opin Biol Ther. 2016; 16(12): 1529-40. PubMed Abstract | Publisher Full Text

111. Hui W, Young DA, Rowan AD, et al.: Oxidative changes and signalling pathways are pivotal in initiating age-related changes in articular cartilage. Ann Rheum Dis. 2016; 75(2): 449-58

PubMed Abstract | Publisher Full Text | Free Full Text

112. F Soul J, Hardingham T, Boot-Handford R, et al:: SkeletalVis: An exploration and meta-analysis data portal of cross-species skeletal transcriptomics data. Bioinformatics. 2018.

PubMed Abstract | Publisher Full Text | F1000 Recommendation

113. Mullen L, Adams G, Layward L, et al.: Latent cytokines for targeted therapy of inflammatory disorders. Expert Opin Drug Deliv. 2014; 11(1): 101-10. PubMed Abstract | Publisher Full Text

114. Vessillier S, Adams G, Montero-Melendez T, et al:: Molecular engineering of short half-life small peptides (VIP, $\alpha \mathrm{MSH}$ and $\gamma_{3} \mathrm{MSH}$ ) fused to latency-associated peptide results in improved anti-inflammatory therapeutics. Ann Rheum Dis. 2012; 71(1): 143-9. PubMed Abstract | Publisher Full Text

115. Evans $\mathrm{CH}$, Kraus VB, Setton LA: Progress in intra-articular therapy. Nat Rev Rheumatol. 2014; 10(1): 11-22.

PubMed Abstract | Publisher Full Text | Free Full Text

116. $\mathrm{F}$ Yan $\mathrm{H}$, Duan $\mathrm{X}, \mathrm{Pan} \mathrm{H}$, et al:: Suppression of NF-кB activity via nanoparticle-based siRNA delivery alters early cartilage responses to injury. Proc Natl Acad Sci U S A. 2016; 113(41): E6199-E6208. PubMed Abstract | Publisher Full Text | Free Full Text | F1000 Recommendation

117. F Geiger BC, Wang S, Padera RF, et al.: Cartilage-penetrating nanocarriers improve delivery and efficacy of growth factor treatment of osteoarthritis. Sci Transl Med. 2018; 10(469): pii: eaat8800. PubMed Abstract | Publisher Full Text | F1000 Recommendation

118. Apte SS, Parks WC: Metalloproteinases: A parade of functions in matrix biology and an outlook for the future. Matrix Biol. 2015; 44-46: 1-6. PubMed Abstract | Publisher Full Text 


\section{Open Peer Review}

\section{Current Peer Review Status:}

\section{Editorial Note on the Review Process}

Faculty Reviews are review articles written by the prestigious Members of Faculty Opinions. The articles are commissioned and peer reviewed before publication to ensure that the final, published version is comprehensive and accessible. The reviewers who approved the final version are listed with their names and affiliations.

\section{The reviewers who approved this article are:}

\section{Version 1}

\section{Richard F. Loeser Jr.}

Thurston Arthritis Research Center, Division of Rheumatology, Allergy and Immunology, University of North Carolina School of Medicine, Chapel Hill, NC, USA

Competing Interests: No competing interests were disclosed.

\section{Christopher Little}

Raymond Purves Bone and Joint Research Laboratories, Kolling Institute of Medical Research, University of Sydney, Sydney, NSW, Australia

Competing Interests: No competing interests were disclosed.

The benefits of publishing with F1000Research:

- Your article is published within days, with no editorial bias

- You can publish traditional articles, null/negative results, case reports, data notes and more

- The peer review process is transparent and collaborative

- Your article is indexed in PubMed after passing peer review

- Dedicated customer support at every stage

For pre-submission enquiries, contact research@f1000.com 